https://helda.helsinki.fi

\title{
Economics of size-structured forestry with carbon storage
}

\section{Assmuth, Aino}

2018-01

Assmuth , A , Ramo , J \& Tahvonen , O 2018 , ' Economics of size-structured forestry with carbon storage ' , Canadian Journal of Forest Research , vol. 48 , no. 1 , pp. 11-22 . https://doi.org/10.1139/cjfr-2017

http://hdl.handle.net/10138/231770

https://doi.org/10.1139/cjfr-2017-0261

acceptedVersion

Downloaded from Helda, University of Helsinki institutional repository.

This is an electronic reprint of the original article.

This reprint may differ from the original in pagination and typographic detail.

Please cite the original version. 
1 Economics of size-structured forestry with carbon storage

2 Aino Assmuth, corresponding author

3 Department of Forest Sciences, University of Helsinki, P.O. Box 27, FI-00014 Helsinki, Finland 4 Tel. +358407331728

5 E-mail: aino.assmuth@helsinki.fi

7 Janne Rämö

8 Department of Forest Sciences, University of Helsinki, P.O. Box 27, FI-00014 Helsinki, Finland 9 E-mail: janne.ramo@helsinki.fi

10

11 Olli Tahvonen

12 Department of Forest Sciences, University of Helsinki, P.O. Box 27, FI-00014 Helsinki, Finland 13 E-mail: olli.tahvonen@ helsinki.fi 


\section{(}

Abstract

We study the economics of carbon storage using a model that includes forest size structure and determines the choice between rotation forestry and continuous cover forestry. Optimal harvests may rely solely on thinning, implying infinite rotation and continuous cover forestry, or both thinning and clearcuts, implying finite rotation periods. Given several carbon prices and interest rates, we optimize the timing and intensity of thinnings along with the choice of management regime. In addition to the carbon storage in living trees, we include the carbon dynamics of dead trees and timber products. Forest growth is specified by an empirically validated transition matrix model for Norway spruce (Picea abies (L.) Karst.). The optimization problem is solved in its general dynamic form by applying bilevel optimization with gradient-based interior point methods and a genetic algorithm. Carbon pricing postpones thinnings, increases stand density by directing harvests to larger trees, and typically yields a regime shift from rotation forestry to continuous cover forestry. In continuous cover solutions, the steady-state harvesting interval and the diameter distribution of standing and harvested trees are sensitive to carbon price, implying that carbon pricing increases the sawlog ratio of timber yields. Additionally, we obtain relatively inexpensive stand-level marginal costs of carbon storage.

Keywords: carbon sequestration, carbon subsidy, continuous cover forestry, management regimes, 7 optimal rotation, uneven-aged forestry 


\section{Introduction}

40 Holding more than double the amount of carbon in the atmosphere, forest ecosystems are a crucial

41 part of the global carbon cycle (FAO 2006). Carbon storage in forests can be maintained and increased by reducing deforestation, by afforestation and by changing stand-level forest management practices (IPCC 2014). While increasing forest cover may be challenging due to competing land uses (Lubowski et al. 2006), enhancing carbon storage per hectare of existing forestland may be a costefficient mitigation option. Our study analyses economically optimal carbon storage in size-structured stands of Norway spruce (Picea abies (L.) Karst.). Unlike previous studies, we apply a forest economic model that encompasses the two alternative forest management regimes: forest management based on clearcuts and management that maintains forest cover continuously. Using this generalized model, we present a detailed analysis of the effects of carbon storage on optimal management practices, including the choice between management regimes. The latter is vital given that climate change adaptation and biodiversity protection may motivate a more widespread application of continuous cover management (Gauthier et al. 2015).

In the boreal region and beyond, forestry has relied heavily on the rotation regime, where forest stands are artificially regenerated and finally clearcut, resulting in more or less even-aged stands (Gauthier et al. 2009). However, planted even-aged forests account for only $13 \%$ of managed forest area globally (FAO 2010, Payn et al. 2015). Further, recent research suggests that plantation forestry may be more vulnerable to disturbances related to climate change than forest management that maintains structurally diverse stands (Gauthier et al. 2015). An alternative to the rotation regime is continuous cover or uneven-aged forestry, where the stand is managed by partial cuttings (i.e. thinnings). Regeneration occurs naturally, resulting in a heterogeneous age and size distribution. In comparison to rotation forestry, continuous cover forestry is likely to support more biodiversity and other ecosystem services (Calladine et al. 2015, O'Hara 2014) and to be more resilient against threats brought about by climate change (Thompson et al. 2009). 
While continuous cover forestry shows promise for climate change adaptation, cost-efficient mitigation measures have been analysed almost exclusively in the framework of rotation forestry. A seminal paper by van Kooten et al. (1995) examines the effect of carbon pricing on optimal rotation age and supply of carbon services. Akao (2011) shows how the effects of carbon storage on optimal rotation age depend on assumptions concerning the carbon release from wood products, while Hoel et al. (2014) extend the van Kooten et al. (1995) framework by including forests' multiple carbon pools, harvest residues and the use of timber for bioenergy. These along with numerous other studies apply the generic version of the Faustmann optimal rotation model, where stands can be harvested solely by clearcutting (Samuelson 1976). As commercial thinnings have an important role in e.g. Nordic context, they have been incorporated into even-aged models with carbon storage by e.g. Huang and Kronrad (2006), Pohjola and Valsta (2007) and Daigneault et al. (2010). Further, Niinimäki et al. (2013) for Norway spruce and Pihlainen et al. (2014) for Scots pine highlight the importance of adapting thinning strategies (in addition to the rotation period) for economically optimal carbon storage.

Studies on optimal carbon storage in continuous cover forestry are scarce, and most of the existing contributions have limited their scope to steady states (e.g. Buongiorno et al. 2012). Goetz et al. (2010) is an exception, as they dynamically optimize timber production and carbon storage in uneven-aged stands of Scots pine in Spain. The question of the relative profitability of rotation $v s$. continuous cover forestry in the co-production of timber and carbon storage has been touched upon in certain studies: Gutrich and Howarth (2007) compare management regimes with carbon storage, but do not optimize the regime choice, while Pukkala et al. (2011) analyse the choice of management regime applying a model without sound economic basis. As far as we know, no studies exist using a detailed dynamic model for analysing the effect of carbon storage on the choice between these two management regimes. 
This gap is not surprising, as up to very recently, the economics of even- and uneven-aged

89 forestry have been analysed separately and with divergent models. While the literature on even-aged forestry builds on Faustmann (1849), the first attempts to optimize uneven-aged management include de Liocourt (1898) and Adams and Ek (1974). As discussed in Getz and Haight (1989, p. 287-295) and Rämö and Tahvonen (2014), many studies have attempted to bypass the dynamic complexities involved in optimizing uneven-aged forestry. However, seminal contributions by Haight (1985) and Haight and Getz (1987) correctly specify the uneven-aged problem as an infinite time horizon problem without ad hoc restrictions. Recently it has been shown that when the optimal choice between continuous cover vs. rotation forestry is determined endogenously, both management regimes can be analysed using the same model (Tahvonen and Rämö 2016). This generalized approach allows for the optimization of stand management - thinnings and the (potentially infinite) rotation age - over an infinite time horizon given any initial state. The study at hand extends this model by including the social value of carbon storage.

Our present study is the first one to apply an empirically validated size-structured growth model to the problem of optimal carbon storage with endogenous choice of management regime. Our study 103 features a detailed economic setup with empirically estimated variable harvesting cost functions, 104 along with fixed harvesting costs that necessitate the optimization of thinning intervals. This not only 105 allows us to obtain the first results on optimal harvest timing in uneven-aged forestry with carbon storage, but is also essential for accurately determining the relative economic performance of the rotation and continuous cover regimes. The effect of carbon storage on the optimal choice between 108 these regimes is a question with major practical implications, but one that has not been satisfactorily 109 studied in the previous literature. Our carbon storage formulation explicitly includes carbon dynamics 110 in the whole tree biomass, in dead tree matter and in timber products with distinct decay rates for 111 sawlog and pulpwood products. By combining detailed economic and ecological models, and by 
112 optimizing not only rotation age but thinnings and the management regime as well, we are able to 113 determine the most cost-efficient methods for enhancing carbon storage in managed forests.

114 We continue by introducing the growth model and the optimization problem. Thereafter we 115 present the empirical parameter values and the computational methods. This is followed by results on 116 optimal stand management, on timber production and carbon storage, and on forestry revenues and 117 carbon storage costs. Finally, we discuss our results by comparing them with earlier studies and draw 118 conclusions.

2. The growth model and the optimization problem

120 We denote the number of trees in size class $s$ at the beginning of period $t$ by $121 x_{s t}, s=1,2, \ldots, n, t=t_{1}, t_{1}+1, \ldots, T+1$. Accordingly, the stand state at period $t$ can be given as $122 \mathbf{x}_{t}=\left[x_{1 t}, x_{2 t}, \ldots, x_{n t}\right]$. Let us denote the fraction of trees moving to size class $s+1$ at period $t$ by $123 \beta_{s}\left(\mathbf{x}_{t}\right), s=1,2, \ldots, n$, where $\beta_{n}\left(\mathbf{x}_{t}\right) \equiv 0$. The natural mortality in size class $s$ at period $t$ is $124 \mu_{s}\left(\mathbf{x}_{t}\right), s=1,2, \ldots, n$. Thus the fraction of trees remaining in the same size class equals

$1251-\beta_{s}\left(\mathbf{x}_{t}\right)-\mu_{s}\left(\mathbf{x}_{t}\right), \quad s=1,2, \ldots, n$. Natural regeneration is described by ingrowth, i.e. trees entering

126 the smallest size class. Ingrowth at the beginning of period $t$ is denoted by $\phi\left(\mathbf{x}_{t}\right)$. Additionally, we 127 denote the number of trees harvested from size class $s$ at the end of period $t$ by $128 h_{s t}, s=1,2, \ldots, n, t=t_{1}, t_{1}+1, . ., T$. Hence, stand development can be described by the difference 129 equations

$$
\begin{aligned}
& x_{1, t+1}=\phi\left(\mathbf{x}_{t}\right)+\left[1-\beta_{1}\left(\mathbf{x}_{t}\right)-\mu_{1}\left(\mathbf{x}_{t}\right)\right] x_{1 t}-h_{1 t}, \\
& x_{s+1, t+1}=\beta_{s}\left(\mathbf{x}_{t}\right) x_{s t}+\left[1-\beta_{s+1}\left(\mathbf{x}_{t}\right)-\mu_{s+1}\left(\mathbf{x}_{t}\right)\right] x_{s+1, t}-h_{s+1, t}, s=1,2, \ldots, \mathrm{n}-2, \\
& x_{n, t+1}=\beta_{n-1}\left(\mathbf{x}_{t}\right) x_{n-1, t}+\left[1-\mu_{n}\left(\mathbf{x}_{t}\right)\right] x_{n t}-h_{n t},
\end{aligned}
$$

133 where $t=t_{1}, t_{1}+1, \ldots, T$. 
We assume that the stand is artificially regenerated after a clearcut, and the time interval

135 between the regeneration activities and the ingrowth of trees into the smallest size class equals a 136 certain number of periods denoted by $t_{1}$. Thus, $t_{1}$ periods after planting, we have an initial stand 137 composed of a given number of trees in size class 1 . The stand is clearcut if the rotation length $138 T \in\left[t_{1}, \infty\right)$ is finite.

Let $w \geq 0\left(€ \mathrm{ha}^{-1}\right)$ denote the cost of artificial regeneration. We denote the discount factor by $140 b=1 /(1+r)$, where $r$ refers to the annual interest rate. The length (in years) of a period is denoted by

$141 \Delta$. Revenues, $R\left(\mathbf{h}_{t}\right)$ from thinning and $R\left(\mathbf{x}_{T}\right)$ from clearcuts, depend on the number and size of 142 trees harvested. The revenues per period are specified as

$$
R\left(\mathbf{h}_{t}\right)=\sum_{s=1}^{n} h_{s t}\left(v_{\sigma, s} p_{\sigma}+v_{\varpi, s} p_{\sigma}\right), t=t_{1}, t_{1}+1, \ldots T
$$

where $v_{\sigma, s}$ and $v_{\varpi, s}$ are the sawlog and pulpwood volumes in a tree of size class $s$, and $p_{\sigma}$ and $p_{\sigma}$ are the respective (roadside) prices $\left(€ \mathrm{~m}^{-3}\right)$. Variable harvesting costs (for cutting and hauling) are given separately for thinning and clearcuts by $C_{i}\left(\mathbf{h}_{t}\right), i=t h, c l$. A fixed harvesting cost denoted by $C_{f}$ covers e.g. the transportation of machinery to the stand site. Because of the fixed cost it may not be optimal to harvest the stand in every period. This is taken into account by the binary variables $\delta_{t} \in\{0,1\}, t=t_{1}, t_{1}+1, \ldots, T$ and by the Boolean operator $h_{t}=\delta_{t} h_{t}$. When the choice is $\delta_{t}=1$, the levels of $h_{s t} \geq 0, s=1,2, \ldots, n$ can be freely optimized. When $\delta_{t}=0$, the only admissible choice is $h_{s t}=0, s=1,2, \ldots, n$.

As carbon storage in forests is a positive externality, we assume a Pigouvian subsidy system resembling the one in van Kooten et al. (1995). Accordingly, society pays the forest owner for the amount of $\mathrm{CO}_{2}$ that is absorbed as the stand grows, and charges for the amount of $\mathrm{CO}_{2}$ that is released as a consequence of harvesting and natural mortality. Let $p_{c} \geq 0\left(€ \mathrm{tCO}_{2}^{-1}\right)$ denote the economic 
value of $\mathrm{CO}_{2}$. We let $\omega_{t}=\sum_{s=1}^{n} x_{s, t}\left(v_{\sigma, s}+v_{\sigma, s}\right)$ denote the merchantable timber volume (i.e. stem volume) of the stand at the beginning of period $t$. Density factor $\rho$ converts stem volume into stem dry mass. In addition to the stem, trees are comprised of non-merchantable matter, i.e. foliage, branches, bark, stumps and roots. Expansion factor $\eta$ converts stem dry mass into whole tree dry mass. Hence, the total tree biomass in the stand at the beginning of period $t$ can be given as $B_{t}\left(\mathbf{x}_{t}\right)=\rho \eta \omega_{t}$, and net biomass growth in period $t$ as $B_{t+1}\left(\mathbf{x}_{t+1}\right)-B_{t}\left(\mathbf{x}_{t}\right)$. The amount of $\mathrm{CO}_{2}$ in one dry mass unit equals $\theta$.

We denote the dry mass of sawlog and pulpwood harvested at the end of period $t$ by $y_{\sigma, t}=\rho \sum_{s=1}^{n} h_{s t} v_{\sigma, s}$ and $y_{\sigma, t}=\rho \sum_{s=1}^{n} h_{s t} v_{\sigma, s}$, respectively. Logging will not instantly release the carbon content of timber into the atmosphere because it is only gradually released from timber products as they decay (Liski et al. 2001). Dead tree matter is created both through natural mortality and from harvest residues (i.e. non-merchantable parts of the harvested trees) left in the forest. The dry mass of dead tree matter formed through natural mortality in period $t$ equals $d_{m, t}=\rho \eta \sum_{s=1}^{n} \mu\left(\mathbf{x}_{t}\right)_{s, t} x_{s, t}\left(v_{\sigma, s}+v_{\sigma, s}\right)$. Further, the dry mass of harvest residues created at the end of period $t$ can be given as $d_{h, t}=(\eta-1)\left(y_{\sigma, t}+y_{\varpi, t}\right)$. We denote the annual decay rates of sawlog, pulpwood and dead tree matter, respectively, by $g_{j}(j=\sigma, \varpi, d)$. The urgency of mitigating climate change implies that society is likely to have a positive time preference for net emissions. It can be shown that, per unit of wood product or dead tree matter, the present value of future emissions due to decay equals $p_{c} \alpha_{j}(r)$, where

$$
\alpha_{j}(r)=\frac{g_{j}}{g_{j}+r}
$$

(cf. Pihlainen et al. 2014, Assmuth and Tahvonen 2017). 
178 be given as

$$
Q_{t}=p_{c} \theta\left\{B_{t+1}\left(\mathbf{x}_{t+1}\right)-B_{t}\left(\mathbf{x}_{t}\right)+\left[1-\alpha_{\sigma}(r)\right] y_{\sigma, t}\left(\mathbf{h}_{t}\right)+\left[1-\alpha_{\sigma}(r)\right] y_{\sigma, t}\left(\mathbf{h}_{t}\right)+\left[1-\alpha_{d}(r)\right]\left(d_{m, t}\left(\mathbf{x}_{t}\right)+d_{h, t}\left(\mathbf{h}_{t}\right)\right)\right\}
$$

for $t=t_{1}, t_{1}+1, \ldots, T$,

where $B_{t+1}\left(\mathbf{x}_{t+1}\right)-B_{t}\left(\mathbf{x}_{t}\right)$ refers to net growth, i.e. the change in biomass net of harvests. The matter (from natural mortality and harvest residue) and its decay.

$$
J\left(\mathbf{x}_{0}, T\right)=\max _{\left\{h_{s t}, \delta_{t}, T \in\left[t_{1}, \infty\right)\right\}} \frac{-w+\sum_{t=0}^{T} Q\left(\mathbf{x}_{t}, \mathbf{h}_{t}\right) b^{\Delta(t+1)}+\sum_{t=t_{1}}^{T}\left[R\left(\mathbf{h}_{t}\right)-C_{i}\left(\mathbf{h}_{t}\right)-\delta_{t} C_{f}\right] b^{\Delta(t+1)}}{1-b^{\Delta(T+1)}}
$$

s.t. (1) - (3) and

$$
\delta_{t} \in\{0,1\}, t=t_{1}, t_{1}+1, \ldots, T
$$

$$
x_{s t} \geq 0, s=1,2, \ldots, n, t=t_{1}, t_{1}+1, \ldots, T+1,
$$

$$
h_{s t}=\delta_{t} h_{s t} \geq 0, s=1,2, \ldots, n, t=t_{1}, t_{1}+1, \ldots, T
$$

(11) $\mathbf{x}_{T+1}=0$,

(12) $x_{s, t_{1}}$ given.

194 The optimal forest management regime is determined by the choice of $T$. If - given optimized 195 thinnings - the objective functional is maximized by a finite rotation age, rotation forestry is optimal. 196 If no maximum exists and the bare land value converges toward the continuous cover forestry bare 197 land value from below as $T \rightarrow \infty$, then it is optimal to apply continuous cover management. 
We apply an empirical growth model by Bollandsås et al. (2008) for Norway spruce at latitude 61.9

${ }^{\circ} \mathrm{N}$. The model has been estimated using the National Forest Inventory of Norway, and includes functions for ingrowth, mortality and diameter increment. We study an average productivity site ( $S I=15)$, implying that the height of the dominant trees at the age of 40 (100) years is 15 (24) metres. We use 12 size classes with diameters (midpoints) ranging from $7.5 \mathrm{~cm}$ to $62.5 \mathrm{~cm}$ with $5.0 \mathrm{~cm}$ intervals. Table 1 presents the size class -specific parameter values (Rämö and Tahvonen 2014). The length of a period $(\Delta)$ is five years and the time interval from planting to the emergence of trees into the first size class is 20 years (i.e. $t_{1}=4$ ). The initial stand structure is given as $\mathbf{x}=[2250,0,0, \ldots]$, i.e. 20 years after artificial regeneration, 2250 trees emerge in the smallest size class.

$\mu_{s t}=\left(1+e^{-\left(-2.492-0.020 M_{s}+3.2 \cdot 10^{-5} M_{s}{ }^{2}+0.031 A_{t}\right)}\right)^{-1}$, where $M_{s}$ is the diameter (midpoint) of size class

211 moving to the next size class during period $t$ is denoted by

$\beta_{s t}=\left(1.2498+0.0476 M_{s}-11.585 \cdot 10^{-5} M_{s}^{2}-0.3412 L_{s t}+0.906 \cdot S I-0.024 A_{t}\right) / 50$

213 where $L_{s t}$ is the total basal area of size classes $s+1, \ldots, n$ at the beginning of period $t$. The estimated 214 number of trees entering the smallest size class (i.e. natural regeneration) during the 5-year period $t$

215 is given as $\phi_{t}=\frac{54.563\left(A_{t}+a\right)^{-0.157} \cdot S I^{0.368}}{1+e^{\left(0.391+0.018 A_{t}-0.066 \cdot S I\right)}}$.

216 Note that $\phi$ is strictly convex in $\mathbf{x}$, implying nonconvexities in the optimization problem. In 217 Bollandsås et al. (2008), $a=0$ and $\phi \rightarrow \infty$ as $\mathbf{x} \rightarrow 0$. This feature is unwarranted, and based on 218 Wikberg (2004) and Pukkala et al. (2009) we set $a=0.741$, which implies $\phi(0)=100$. This 
correction parameter decreases the ingrowth by less than one tree per year when basal area is above $2 \mathrm{~m}^{2}$.

The roadside prices for sawtimber and pulpwood are $€ 58.44 \mathrm{~m}^{-3}$ and $€ 34.07 \mathrm{~m}^{-3}$, respectively. The fixed harvesting cost equals $€ 500 \mathrm{ha}^{-1}$. For the variable harvesting costs we use empirically estimated functions by Nurminen et al. (2006), based on the performance of modern harvesters. The variable harvesting costs (cutting and hauling) depend on the number and volumes of trees cut, and are given separately for thinning and clearcuts as

$C_{i}=C_{i 0} C_{i 1} \sum_{s=1}^{n} h_{s t}\left(C_{i 2}+C_{i 3} v_{s}-C_{i 4} v_{s}^{2}\right)+C_{i 5}\left[C_{i 6} \sum_{s=1}^{n} h_{s t} v_{s}+C_{i 7}\left(\sum_{s=1}^{n} h_{s t} v_{s}\right)^{0.7}\right], i=t h, c l$.

$C_{i 0}$ is the per-minute cutting cost $(€)$, and its coefficient $C_{i 1}(\bullet)$ is the time (in minutes) spent cutting one tree and moving the machinery to the next tree. $C_{i 5}$ and its coefficient $[\bullet]$ are the cost and time spent in hauling, respectively, while $v_{s}=v_{\sigma, s}+v_{\sigma, s}$ is the volume of a tree in size class $s$. The parameter values for $C_{i k}, i=t h, c l, k=0, \ldots, 7$ are given in Table 2 . The parameter $C_{t h 1}=1.150$ in the cutting cost element for thinning takes into account that cutting one tree and moving to the next one is more costly in (continuous cover) thinning compared to clearcuts (Surakka and Siren 2007). Additionally, hauling is more time-consuming in thinnings than in clearcuts. The cost of artificial regeneration is $€ 1000-1500$ ha $^{-1}$ (Niinimäki et al. 2012). We apply the lower bound because this will reveal how carbon storage alters the choice between continuous cover and rotation forestry.

Based on Lehtonen et al. (2004), the stemwood density factor ( $\rho$ ) for Norway spruce is 0.3774 tonnes of dry matter per cubic metre of fresh volume, and the expansion factor to convert stem dry mass into whole tree dry mass $(\eta)$ equals 2.1566 . Following Niinimäki et al. 2013, the $\mathrm{CO}_{2}$ content 239 of a wood dry mass unit $(\boldsymbol{\theta})$ is obtained by multiplying the share of carbon in biomass dry weight 240 (0.5) with the coefficient that converts tonnes of carbon to tonnes of $\mathrm{CO}_{2}(44 / 12)$. Thus we set $241 \theta=1.83333 \mathrm{tCO}_{2} \mathrm{t}^{-1}$. For the decay rate of dead tree matter we use $g_{d}=0.18196$ based on the average 
rate of stem, foliage, branches, bark, stumps and roots in Hyvönen and Ågren (2001). To obtain the

243 decay rates for sawlog and pulpwood products we use data presented in Liski et al. (2001) on the

244 division of sawlog and pulpwood removals for production lines, on production losses, and on the

245 division into timber product types with different lifespans. The obtained parameter values are $g_{\sigma}=$

$246 \quad 0.06611$ and $g_{\varpi}=0.47070$.

\section{Computational methods}

Because the harvest timing variables are integers, but harvest intensities are continuous, the task is to solve a mixed-integer nonlinear programming problem. To do this, we apply bilevel optimization (Colson et al. 2007). ${ }^{1}$ The lower-level problem is computed using version 9.0 of the Knitro optimization software, which applies advanced gradient-based interior point algorithms (Byrd et al. 2006). The maximized objective value of the lower-level problem forms the objective value given any vector of harvest timing binaries. The harvest timing vector is optimized using a genetic algorithm (Deb and Sinha 2010, Sinha et al. 2017). The optimal harvest schedules are solved for a series of rotation lengths. If the objective function obtains a maximum with some $T \in[60,180)$ years, the optimal rotation is finite. If the value of the objective function continues to increase as the rotation period is lengthened, the optimal rotation is infinite. In this case, the optimal continuous cover solution is obtained by lengthening the horizon to obtain a close approximation of the infinite horizon solution. To handle potential non-convexities, we apply multiple randomly chosen initial points in the optimization. For the genetic algorithm, we use a randomly generated initial population of 40 harvest timing vectors, and for each harvest intensity optimization we use four random initial points. These values were found to be sufficient for finding the same local optimum as a higher number of initial guesses. Using efficient parallel computation (Intel (R) Xeon (R)E5-2643 v3 @ 3.40GHZ, 24

\footnotetext{
${ }^{1}$ A similar approach has been applied to a forest management problem without carbon storage in Tahvonen and Rämö
} (2016). 
logical processors), the optimal harvest intensity and timing is found within $3-36 \mathrm{~h}$. The solution

265 times for the lower lever problem are typically 5-15 seconds with approximately $20 \%$ variability in 266 the objective values of the local optima based on different initial points.

\section{Results}

The effects of carbon pricing on optimal stand management

For reference, we first briefly state results for the generic Faustmann setting (Samuelson 1976), where harvesting can be carried out solely in clearcuts (i.e. no thinnings), and no natural regeneration takes place. This setting is similar to that of the carbon storage study by van Kooten et al. (1995). Given an annual interest rate of $2 \%$, with zero carbon price, the optimal rotation age is 60 years. Setting a carbon price of $€ 20(€ 30) \mathrm{tCO}_{2}^{-1}$ lengthens the optimal rotation period to 65 (70) years, while a carbon price of $€ 60 \mathrm{tCO}_{2}^{-1}$ implies a 90 -year rotation period. Given a $4 \%$ annual interest rate, the effect of carbon pricing on rotation length is somewhat stronger. Increasing the carbon price from zero to $€ 60$ $\mathrm{tCO}_{2}{ }^{-1}$ increases the optimal rotation age from 50 years to 110 years.

We now turn to the full economic setup with optimized intensity and timing of thinnings along with an optimized rotation period and management regime. Given a $2 \%$ annual interest rate, optimal rotation age increases with carbon price (Table 3, Figure 1). The optimal rotation length without carbon pricing equals 130 years. The relatively long rotation follows from optimally utilizing natural regeneration. When carbon price equals $€ 10(€ 20) \mathrm{tCO}_{2}{ }^{-1}$, the rotation age is 150 (170) years. Given a carbon price of $€ 30 \mathrm{tCO}_{2}^{-1}$ or higher, the optimal rotation period is infinitely long, implying that continuous cover forestry is superior to rotation forestry. Given a $4 \%$ interest rate, the optimal rotation is infinite even with zero carbon price (Table 3, Figure 2). This is because a high interest rate makes it optimal to postpone or avoid the investment in artificial regeneration, as natural regeneration maintains a sufficient level of growth without costs. Moreover, a higher interest implies lower optimal 
stocking and thus a smaller opportunity cost of delaying the clearcut. Additionally, the time delay

289 between stand regeneration and the first revenues from thinnings becomes costly when discounting

290 is heavier. This encourages a shift to continuous cover forestry with more frequently repeated 291 harvests. thinning is invariably performed from above, always fully cutting down the largest harvested size 294 class. Relative value growth is very high in small trees, implying that it is optimal to postpone harvesting until they have grown to a size that yields sawlog. Given a $2 \%$ interest rate and zero carbon price, the first thinning takes place 45 years after stand regeneration (Table 3, Figure 1). Carbon pricing postpones the first thinning by five years, and increases mean stand volume along the rotation - or, in the case of continuous cover solutions, at the steady state (Table 3). The timing and intensity of subsequent thinnings can be seen in Figure 1, where stand volume and the number of trees drop after each harvest. Given a $4 \%$ interest rate and no carbon pricing, the first thinning is carried out already at a stand age of 40 years (Table 3, Figure 2), as it is optimal to maintain less capital in the stand. A carbon price of $€ 20(€ 60) \mathrm{tCO}_{2}^{-1}$ postpones the first thinning by five (15) years.

The relative effect of carbon pricing on optimal stand management and stand density is larger with a higher interest rate. Given a $2 \%$ interest rate, mean stand volumes range from 138 to $224 \mathrm{~m}^{3}$ $\mathrm{ha}^{-1}$ for carbon prices $€ 0-€ 60 \mathrm{tCO}_{2}^{-1}$; given a $4 \%$ interest rate the corresponding mean stand volumes span from 68 to $234 \mathrm{~m}^{3} \mathrm{ha}^{-1}$ (Table 3). From the economic point of view, forest carbon storage 307 essentially means shifting net emissions forward in time. Thus stronger discounting implies a stronger 308 incentive to adapt forest management to provide more carbon storage.

The higher the carbon price, the larger the harvested trees at the continuous cover steady states

310 (Table 3, Figure 3). Additionally, the number of size classes harvested equals the number of five-year 311 periods between the steady-state harvests. Given a $2 \%$ interest rate and a carbon price of $€ 30 \mathrm{tCO}_{2}{ }^{-1}$, 312 trees are harvested from five size classes in the optimal continuous cover solution (diameter midpoints 
$32.5,37.5,42.5,47.5$ and $52.5 \mathrm{~cm}$ ) with a 25 -year interval. When carbon price increases to $€ 60 \mathrm{tCO}_{2}{ }^{-}$

314 , it is optimal to forgo harvesting the $32.5 \mathrm{~cm}$ diameter class and to only cut trees with diameters of $31537.5-52.5 \mathrm{~cm}$. This is achieved by switching to a 20 -year harvesting interval (Table 3 ). Thus harvest 316 timing adjusts to the carbon price to maintain optimal average stand density and economic return 317 (including carbon subsidies) along the harvest interval.

Given a $4 \%$ interest rate and zero carbon price, the steady-state harvest takes place every 20 years, and targets trees with diameters of $22.5-37.5 \mathrm{~cm}$ (Table 3, Figure 3). With a $€ 10 \mathrm{tCO}_{2}{ }^{-1}$ carbon price, the steady-state harvesting interval equals 25 years, allowing some trees to enter the $42.5 \mathrm{~cm}$ size class before they are harvested. Increasing the carbon price further shifts the steady-state harvests to larger size classes, implying a higher mean stand volume. While the number of trees decreases with tree size class (Figure 3, column a), large trees comprise a considerable fraction of the total stem volume because of their high volume per tree (Figure 3, column b).

Given a $2 \%$ interest rate and zero carbon price, mean annual sawlog yield over the rotation equals 6.3 $\mathrm{m}^{3} \mathrm{ha}^{-1}$, while mean annual total yield (sum of sawlog and pulpwood) equals $7.6 \mathrm{~m}^{3} \mathrm{ha}^{-1}$ (Table 4). Increasing the carbon price to $€ 10(€ 20) \mathrm{tCO}_{2}{ }^{-1}$ increases mean sawlog yield to $6.5(6.7) \mathrm{m}^{3} \mathrm{ha}^{-1}$ while total yield remains unchanged, i.e. the sawlog-pulp ratio increases. This has a positive effect on 331 carbon storage because the typical decay rate of sawlog products is notably slower than that of 332 pulpwood. Increasing the carbon price to $€ 30 \mathrm{tCO}_{2}^{-1}$ implies a regime shift from rotation forestry to 333 continuous cover forestry, and decreases mean sawlog and total yield while increasing the sawlog 334 ratio. The explanation is that continuous cover management tends to produce somewhat lower mean 335 yields than rotation forestry, even when the bare land value of the former is higher. Increasing the carbon price further, to $€ 60 \mathrm{tCO}_{2}^{-1}$, has only a negligible effect on mean sawlog and total yields. 
Given a $4 \%$ interest rate and no carbon pricing, mean sawlog and total yields are low, 3.8 and $3384.5 \mathrm{~m}^{3} \mathrm{ha}^{-1} \mathrm{a}^{-1}$, respectively (Table 4). This is due to the low optimal level of growing capital. With 339 carbon pricing, trees are allowed to grow bigger before they are harvested (Table 3), which increases 340 yields when the carbon price is relatively low. For example, given a carbon price of $€ 30 \mathrm{tCO}_{2}^{-1}$, the 341 mean sawlog yield equals $5.7 \mathrm{~m}^{3} \mathrm{ha}^{-1}$ and mean total yield is $6.7 \mathrm{~m}^{3} \mathrm{ha}^{-1}$. However, with $€ 60 \mathrm{tCO}_{2}{ }^{-1}$ 342 carbon price, mean sawlog and total yields equal 5.6 and $5.8 \mathrm{~m}^{3} \mathrm{ha}^{-1}$, respectively (Table 4). This 343 implies that when the carbon price is sufficiently high, yields begin to decrease with carbon price 344 because only very large trees are harvested.

Natural mortality remains rather low in economically optimal solutions, but dead tree matter is generated from harvest residues. Each harvest decreases the carbon storage in living trees, but causes a temporary increase in carbon storage in dead tree matter and in timber products (Figure 4). The 348 latter two, however, quickly decrease as a consequence of decay. This is especially true for clearcuts 349 (Figure $4 \mathrm{a}-\mathrm{c}$ ), which yield large amounts of rapidly decaying pulpwood. Because of exponential decay, the initial carbon stocks in dead tree matter and in timber products reach a steady state, where total carbon storage at the beginning of the rotation equals total carbon storage at the end of the rotation. In continuous cover solutions (Figure 4d), carbon stocks in living trees, dead tree matter and 353 timber products go through a transition phase before reaching a steady state. Mean carbon storage in living trees increases with carbon price (Table 4). For example, given 355 a $2 \%$ interest rate and no carbon pricing, the average amount of carbon stored in living trees over a 356 rotation is $207 \mathrm{tCO}_{2} \mathrm{ha}^{-1}$; increasing the carbon price to $€ 60 \mathrm{tCO}_{2}^{-1}$ increases mean storage to 335 $357 \mathrm{tCO}_{2} \mathrm{ha}^{-1}$. Additionally, mean carbon storage in dead tree matter and timber products generally 358 increase with carbon price. An exception is the regime shift from rotation forestry to continuous cover 359 forestry ( $2 \%$ interest rate, carbon price from $€ 20$ to $\left.€ 30 \mathrm{tCO}_{2}^{-1}\right)$. As mentioned, rotation forestry 360 produces high total yields and thus large amounts of harvest residues, and average natural mortality 361 is somewhat higher in rotation forestry than in continuous cover forestry. Moreover, the calculation 
of mean carbon storage in dead tree matter and timber products takes into account the accumulation

363 of these stocks from one rotation to the next.

In solutions where continuous cover management is optimal, the steady state may be reached

365 as late as approximately 300 years after stand regeneration. This implies that in terms of economic 366 outcome, the carbon storage taking place during the long transition phase towards the steady state is 367 likely to be more important than mean carbon storage. Discounted $\mathrm{CO}_{2}$ sequestration $\left(\mathrm{tCO}_{2} \mathrm{ha}^{-1}\right)$ is 368 the sum of all periodic net carbon fluxes within the infinite planning horizon, each discounted to the 369 present (stand regeneration) moment. For example, given a $2 \%$ interest rate and a carbon price of $€ 20$ $370 \mathrm{tCO}_{2}^{-1}$, the net carbon sequestration over the infinite horizon is equivalent to 232 tonnes of $\mathrm{CO}_{2}$ 371 emissions abated immediately. Discounted $\mathrm{CO}_{2}$ sequestration increases monotonously with carbon 372 price (Table 4).

373 Forestry revenues and the cost of carbon storage

374 The higher the carbon price, the lower the discounted timber income (Table 5). This is true despite of 375 the fact that the mean timber yields do not monotonically decrease with carbon price (Table 4). The 376 decrease in discounted timber income is partly explained by differences in harvest timing: when 377 carbon storage is valued, harvests are carried out later. Additionally, deviating from the optimal 378 timber-only solution implies higher harvesting costs per timber unit. However, the decrease in timber 379 income is more than compensated by carbon subsidies that represent the economic value of carbon 380 storage. Including carbon storage benefits improves net present values (i.e. bare land value) 381 considerably: given a $2 \%(4 \%)$ interest rate, a carbon price of $€ 20 \mathrm{tCO}_{2}^{-1}$ increases net present value 382 by $50 \%(137 \%)$ (Table 5). If the social value of carbon storage is high (€30 or $€ 60 \mathrm{tCO}_{2}{ }^{-1}$ depending 383 on interest rate), the economic benefits from carbon storage clearly overweigh the income from timber 384 production.

The economic cost of additional carbon storage, i.e. the cost of carbon abatement in forestry, is 
decrease (i.e. from the solution with a lower carbon price) in timber income for each optimal solution

388 by the corresponding incremental increase in discounted $\mathrm{CO}_{2}$ sequestration. ${ }^{2}$ Marginal abatement 389 costs increase with the amount of carbon abatement (Figure 5). Given a 2\% interest rate, marginal 390 costs range from $€ 3$ to $€ 46 \mathrm{tCO}_{2}^{-1}$ for 10 to 70 tonnes of carbon abatement per hectare. Given a $4 \%$ 391 interest rate abatement is somewhat more costly, but carbon abatement up to 33 tonnes per hectare 392 can be achieved with a marginal cost below $€ 40 \mathrm{tCO}_{2}^{-1}$.

\section{Discussion and conclusions}

It is widely established in the literature that valuing carbon storage increases optimal rotation age in even-aged forestry (e.g. van Kooten et al. 1995, Stainback and Alavalapati 2002, Gutrich and Howarth 2007, Pohjola and Valsta 2007). While our findings support this result, our model differs from previously published models in many important aspects and is able to shed light on previously unaddressed questions. Unlike many studies, we include thinnings, and optimize their timing along with their intensity. Further, we determine the optimal management regime - rotation forestry or continuous cover forestry - endogenously. As far as we know, such an optimization approach has not been combined with carbon storage using a size-structured description of forest resources.

Including thinnings (and natural regeneration) is essential for our approach, because it implies 403 that timber revenues may be obtained from a forest that is never clearcut. This is not the case in 404 studies applying the classic Faustmann rotation model, e.g. van Kooten et al. (1995) and Hoel et al. 405 (2014). van Kooten et al. (1995) find that carbon pricing generally increases rotation ages only 406 moderately, but in certain cases might yield a result where it is optimal to forgo harvesting completely. 407 Hoel et al. (2014) show that rotation age typically increases with the social cost of carbon and may 408 become infinitely long (i.e. forestry is abandoned). According to our results, carbon pricing may 409 indeed render the optimal rotation infinitely long, but instead of total abandonment of harvesting as

\footnotetext{
${ }^{2}$ Note that an amount of discounted $\mathrm{CO}_{2}$ sequestration corresponds to an equal amount of emissions abated immediately.
} 
in van Kooten et al. (1995) and Hoel et al. (2014), it then becomes optimal to manage the stand with

411 thinnings (i.e. apply continuous cover forestry).

According to studies that included optimized thinnings in their even-aged setup (e.g. Pohjola and Valsta 2007, Daigneault et al. 2010, Niinimäki et al. 2013), carbon pricing tends to postpone thinnings, increase mean stand volume and lengthen the optimal rotation period. Our results support these findings. However, our generalized model yields optimal solutions that go beyond the scope of earlier studies limited to forests without natural regeneration. Given the low interest rate (2\%), optimal rotations are long, ranging from 130 to 170 years for carbon prices $€ 0-€ 20 \mathrm{tCO}_{2}^{-1}$. With a $€ 30 \mathrm{tCO}_{2}^{-1}$ carbon price, clearcutting is suboptimal, i.e. the optimal management regime switches from rotation forestry to continuous cover forestry. Given a higher interest rate (4\%), continuous cover forestry dominates rotation forestry regardless of carbon price ${ }^{3}$, and management adapts to carbon pricing by changing the timing and targeting of thinnings.

In our model setup, it is possible to exclude natural regeneration by setting $\phi\left(\mathbf{x}_{t}\right)=0$ in Eq. 1 (implying that any naturally regenerated saplings are cleared away, and the clearing is costless). If this is done, we obtain optimal rotation ages that are well in line with those obtained in earlier studies on even-aged Norway spruce: the study by Solberg and Haight (1991) based on a size-structured growth model, and the study by Niinimäki et al. (2013) utilizing a highly detailed process-based model. Without natural regeneration and given a $2 \%$ interest rate, our optimal rotation lengths range from 100 to 155 years for carbon prices $€ 0-€ 60 \mathrm{tCO}_{2}{ }^{-1}$. Given a $4 \%$ interest rate, rotation periods for carbon prices $€ 0-€ 30 \mathrm{tCO}_{2}^{-1}$ span from 100 to 130 years, while a carbon price of $€ 60 \mathrm{tCO}_{2}^{-1}$ yields an optimal rotation as long as 215 years.

With the exception of Goetz et al. (2010), studies on uneven-aged management with carbon storage tend to apply static optimization, which does not allow optimizing stand transition from any

\footnotetext{
${ }^{3}$ This is in line with Tahvonen and Rämö (2016), where high site productivity, low interest rate and low regeneration cost favour the clearcut regime instead of continuous cover regime, and vice versa.
} 
433 initial state that is not close to the steady state (e.g. Pukkala et al. 2011, Buongiorno et al. 2012).

434 Further, as far as we know, our study presents the first results on optimal harvest timing in uneven435 aged forestry with carbon storage. Our results suggest that when beginning with bare land, the large 436 initial cohorts are intensively utilized in a series of thinnings before approaching the steady state, and 437 that these thinnings are postponed and moderated by carbon pricing. Reaching the steady state may 438 take as much as 300 years from stand regeneration, which emphasizes the importance of the transition 439 phase for the present value of net revenues from both timber production and carbon storage. We also 440 show that the steady-state harvesting interval, along with the diameter distribution of the standing and 441 harvested trees, react to changes in carbon price. The average size of the harvested trees increases 442 with carbon price, and four (or five) diameter classes are fully harvested each 20 (25) years at the 443 steady state.

444 The carbon storage formulation presented in van Kooten et al. (1995) takes into account that 445 while carbon is stored in living trees, it may also be stored to some extent in timber products. We add 446 detail to this formulation by explicitly including carbon storage in timber products and in dead tree 447 matter. Our results suggest that a small carbon stock is maintained in dead tree matter, formed from 448 harvest residues and through natural mortality. To account for carbon storage in timber products, we 449 use distinct decay rates for sawlog and pulpwood (cf. Pihlainen et al. 2014). This is important because 450 our size-structured model enables us to direct thinnings to trees of specific size, making use of the 451 fact that large trees yield relatively more sawlog than small trees. Sawlog, in turn, is superior to 452 pulpwood in its ability to store carbon for extended periods. Such targeted harvesting is by definition 453 impossible in clearcuts, which inevitably results in the harvesting of quickly decaying pulpwood. This 454 becomes costly with a high carbon price. Hence the impact of carbon storage on the relative 455 profitability of rotation forestry $v s$. continuous cover forestry cannot be fully captured by a model that omits the size structure of the stand, or the varying decay profiles of timber assortments. According 
to our results, carbon pricing indeed increases the sawlog-pulp ratio of the mean annual yield and may induce a regime shift to continuous cover forestry.

The model developed in this study is a stand-level model, and thus does not include market interactions. However, our results yield some initial understanding on the effects of carbon storage on wood supply. In general, carbon pricing increases mean total annual yields, mostly due to increased sawlog production. The only exception to this is the case with a low interest rate (2\%), where a carbon price of $€ 30 \mathrm{tCO}_{2}^{-1}$ induces a shift from rotation forestry to continuous cover management with somewhat lower mean yields. Given an interest rate equal or above $4 \%$, continuous cover management with fairly low stand density is optimal when carbon storage is not valued, and carbon pricing clearly increases stocking levels along with the yields.

The cost of artificial regeneration has a large effect on the relative profitability of continuous cover and rotation forestry (Tahvonen and Rämö 2016). In this study, we have assumed the cost of 469 artificial regeneration to be $€ 1000 \mathrm{ha}^{-1}$, which is on the lower side of the typical cost range in Finland. 470 If the regeneration cost is set higher, e.g. $€ 2000$, continuous cover management is optimal regardless 471 of carbon price even with low interest rates. Low site productivity has a similar effect.

McKinsey \& Company (2009) estimates a global abatement potential of almost $8000 \mathrm{MtCO}_{2}$ 473 per year in the forestry sector for a marginal cost range from $€ 2$ to $€ 28 \mathrm{tCO}_{2}{ }^{-1}$. In van Kooten et al. (2009), a meta-regression analysis of forest carbon storage costs is performed using 1047 observations from 68 studies. Depending on the regression model used, the authors obtain highly 476 varying estimates on the marginal costs of carbon storage. According to van Kooten et al. (2009), 477 storage costs are higher in the boreal region than in the tropics or than the global average. Within the 478 boreal region, their estimates are roughly equal to $€ 4-€ 94 \mathrm{tCO}_{2}^{-1}$ for plantation activities and 34$479 € 155 \mathrm{tCO}_{2}^{-1}$ for adaptation of forest management. However, Niinimäki et al. (2013) show that optimizing the stand management of Norway spruce yields additional discounted carbon storage up 
to $40 \mathrm{tCO}_{2}$ ha ${ }^{-1}$ with marginal costs in the range of $€ 6-€ 36 \mathrm{tCO}_{2}{ }^{-1} \cdot{ }^{4}$ Our results, obtained using a stand482 level model with optimized management regime choice, point to a cost range of $€ 5-€ 47 \mathrm{tCO}_{2}^{-1}$ with 483 as much as $70 \mathrm{tCO}_{2} \mathrm{ha}^{-1}$ of abatement potential. This suggests that if all relevant aspects of forest management adaptation are optimized, increasing carbon storage can be relatively inexpensive even in the boreal region.

In 2015 the European Union (EU) committed to reducing its domestic greenhouse gas emissions by at least 40\% from the 1990 level by 2030 (European Commission 2015). According to an impact assessment by the Commission, fulfilling this commitment would imply a carbon price in the range of $€ 11-€ 53 \mathrm{tCO}_{2}^{-1}$ (depending on policy scenario) in the EU Emissions Trading Scheme (ETS) by 2030. The range of projected prices in 2050 is $€ 85-€ 264 \mathrm{tCO}_{2}^{-1}$ (European Commission 2014, p. 80-

81.) Such carbon price levels would incentivize major changes in forest management, if carbon storage in forests was linked to the ETS. Currently, however, New Zealand is the only country that has integrated forest carbon storage in its emissions trading system (Adams and Turner 2012). Whether or not similar approaches will be adopted in the EU and elsewhere, forest carbon storage is likely to play an important role in any cost-effective climate change abatement strategy.

We have presented a way to study economically optimal carbon storage in forestry without 497 limiting the analysis to either even-aged or uneven-aged forestry. By determining the optimal management regime endogenously, we can cover both regimes simultaneously and analyse the effect of carbon storage on the optimal choice between them. We show that higher stand density, long rotations and a possible switch to continuous cover management, with an emphasis on harvesting 501 large trees with a high sawlog ratio, are the economically efficient carbon abatement methods in stand management. Optimal regime shifts between rotation forestry and continuous cover forestry in sizestructured stands have not previously been addressed in the carbon storage literature. The importance

\footnotetext{
${ }^{4}$ Goetz et al. (2010) present even lower cost ranges for uneven-aged forestry in Spain, especially if soil carbon is taken into account.
} 
504 of our results is further emphasized by recent arguments that forest heterogeneity (age, size and 505 species structure) may improve forest resilience under disturbances caused by climate change 506 (Gamfeldt et al. 2015). The next step, then, will be to optimize carbon storage and wood production 507 in mixed-species stands. 


\section{References}

Adams, D.M., and Ek, A.R. 1974. Optimizing the management of uneven-aged forest stands. Canadian Journal of Forest Research 4(3): 274-287.

Adams, T., and Turner, J.A. 2012. An investigation into the effects of an emissions trading scheme on forest management and land use in New Zealand. Forest Policy and Economics 15: 78-90.

Akao, K.I. 2011. Optimum forest program when the carbon sequestration service of a forest has value. Environmental Economics and Policy Studies 13(4): 323-343.

Assmuth, A., and Tahvonen, O. 2017. Optimal carbon storage in even- and uneven-aged forestry. Forest Policy and Economics, in print.

Bollandsås, O.M., Buongiorno, J., and Gobakken, T. 2008. Predicting the growth of stands of trees of mixed species and size: A matrix model for Norway. Scandinavian Journal of Forest Research 23: 167-178.

Buongiorno, J., Halvorsen, E.A., Bollandsås, O.M., Gobakken, T., and Hofstad, O. 2012. Optimizing management regimes for carbon storage and other benefits in uneven-aged stands dominated by Norway spruce, with a derivation of the economic supply of carbon storage. Scandinavian Journal of Forest Research 27(5): 460-473.

Byrd, R.H., Nocedal J., and Waltz, R.A. 2006. KNITRO: An integrated package for nonlinear optimization. In: di Pillo G. and Roma, M. (eds.) Large-Scale Nonlinear Optimization. Springer, US. p. 35-59.

Calladine, J., Bray, J., Broome, A., and Fuller, R.J. 2015. Comparison of breeding bird assemblages in conifer plantations managed by continuous cover forestry and clearfelling. Forest Ecology and Management 344: 20-29. 
Colson, B., Marcotte, P., and Savard G., 2007. An overview of bilevel optimization. Annals of Operational Researc 153: 235-256.

Daigneault, A.J., Miranda, M. J., and Sohngen, B. 2010. Optimal Forest Management with Carbon Sequestration Credits and Endogenous Fire Risk. Land Economics 86(1): 155-172.

Deb, K., and Sinha A. (2010) An efficient and accurate solution methodology for bilevel multiobjective programming problems using a hybrid evolutionary-local-search algorithm. Evolutionary Computation Journal, 18(3):403-449.

de Liocourt, F. 1898. De l'aménagement des sapinières. Bull. Soc. Franche-Comté et Belfort.

European Commission. 2014. Impact Assessment SWD (2014), 15 final. Accompanying the document Communication from the Commission to the European Parliament, the Council, the European Economic and Social Committee and the Committee of the Regions. A policy framework for climate and energy in the period from 2020 up to $2030.234 \mathrm{p}$.

European Commission. 2015. Intended Nationally Determined Contribution of the EU and its Member States. Submission by Latvia and the European Commission on behalf of the European Union and its Member States.

https://ec.europa.eu/clima/sites/clima/files/docs/2015030601_eu_indc_en.pdf, accessed 29.1.2017.

FAO. 2006. Global Forest Resources Assessment 2005. Progress towards sustainable forest management. FAO Forestry paper 147. Food and Agriculture Organization of the United Nations, Rome. 320 p.

FAO. 2010. Global Forest Resources Assessment 2010. Main report. FAO Forestry Paper 163.

Faustmann, M. 1849. Berechnung des Werthes, welchen Waldboden, sowie noch nicht haubare Holzbestände für die Waldwirthschaft besitzen. Allgemeine Forst- und Jagd-Zeitung 25: 441455. 
Gamfeldt, L., Snäll, T., Bagchi, R., Jonsson, M., Gustafsson, L., Kjellander, P., Ruiz-Jaen, M.C., Fröberg, M., Stendahl, J., Philipson, C.D., Mikusinski, G., Andersson, E., Westerlund, B., Andrén, H., Moberg, F., Moen, J., and Bengtsson, J. 2013. Higher levels of multiple ecosystem services are found in forests with more tree species. Nature Communications 4(1340): 1-8.

Gauthier, S., Vaillancourt, M-A., Kneeshaw, D., Drapeau, P., De Grandpré, L., Claveau, Y., and Paré, D. 2009. Forest Ecosystem Management: Origins and Foundations. In: Gauthier, S., Vaillancourt, M-A., Leduc, A., De Grandpré, L., Kneeshaw, D., Morin, H., Drapeau, P., and Bergeron, Y. (eds.) Ecosystem Management in the Boreal Forest. Presses de l'Université du Québec, Quebec. p. 13-37.

Gauthier, S., Bernier, P., Kuuluvainen, T., Shvidenko, A.Z., and Schepaschenko, D.G. 2015. Boreal forest health and global change. Science 349 (6250): 819-822.

Getz, W.M., and Haight, R.G. 1989. Population Harvesting: Demographic Models for Fish, Forest and Animal Resources. Princeton University Press, New Jersey. 408 p.

Goetz, R-U., Hritonenko, N., Mur, R.J., Xabadia, A., and Yatsenko, Y. 2010. Forest Management and Carbon Sequestration in Size-Structured Forests: The Case of Pinus sylvestris in Spain. Forest Science 56: 242-256.

Gutrich, J., and Howarth, R.B. 2007. Carbon sequestration and the optimal management of New Hampshire timber stands. Ecological Economics 62: 441-450.

Haight, R.G. 1985. Comparison of Dynamic and Static Economic Models of Uneven-aged Stand Management. Forest Science 31: 957-974.

Haight, R.G., and Getz, W.M. 1987. Fixed and equilibrium endpoint problems in uneven-aged stand management. Forest Science 33: 903-931.

Hoel, M., Holtsmark, B., and Holtsmark, K. 2014. Faustmann and the climate. Journal of Forest Economics 20(2): 192-210. 
Huang, C-H., and Kronrad, G.D. 2006. The Effect of Carbon Revenues on the Rotation and Profitability of Loblolly Pine Plantations in East Texas. Southern Journal of Applied Forestry 30(1): 21-29.

Hyvönen, R., and Ågren, G. 2001. Decomposer invasion rate, decomposer growth rate, and substrate chemical quality: how they influence soil organic matter turnover. Canadian Journal of Forest Research 31: 1594-1601.

IPCC. 2014. Summary for Policymakers. In: Core Writing Team, Pachauri, R.K. and Meyer, L.A. (eds.) Climate Change 2014: Synthesis Report. Contribution of Working Groups I, II and III to the Fifth Assessment Report of the Intergovernmental Panel on Climate Change. IPCC, Switzerland. p. 2-31.

Lehtonen, A., Mäkipää, R., Heikkinen, J., Sievänen, R., and Liski, J. 2004. Biomass expansion factors (BEFs) for Scots pine, Norway spruce and birch according to stand age for boreal forests. Forest Ecology and Management 188(1): 211-224.

Liski, J., Pussinen, A., Pingoud, K., Mäkipää, R., and Karjalainen, T. 2001. Which rotation length is favourable to carbon sequestration? Canadian Journal of Forest Research 31: 2004-2013.

Lubowski, R.N., Plantinga, A.J., and Stavins, R.N. 2006. Land-use change and carbon sinks: econometric estimation of the carbon sequestration supply function. Journal of Environmental Economics and Management 51(2): 135-152.

McKinsey \& Company. 2009. Pathways to a Low-Carbon Economy. Version 2 of the Global Greenhouse Gas Abatement Cost Curve. Report. https://www.cbd.int/financial/doc/Pathwaystoalowcarboneconomy.pdf, accessed 30.6.2017.

Niinimäki, S., Tahvonen, O., and Mäkelä, A. 2012. Applying a process-based model in Norway spruce management. Forest ecology and management 265: 102-115. 
Niinimäki, S., Tahvonen, O., Mäkelä, A., and Linkosalo, T. 2013. On the economics of Norway spruce stands and carbon storage. Canadian Journal of Forest Research 43(7): 637-648.

Nurminen, T., Korpunen, H., and Uusitalo, J., 2006. Time consumption analysis of the mechanized cut-to-length harvesting system. Silva Fennica 40: 335-363.

O'Hara, K. 2014. Multi-aged silviculture. Oxford University Press, Oxford. 240 p.

Payn, T., Carnus, J. M., Freer-Smith, P., Kimberley, M., Kollert, W., Liu, S., Orazio, C., Rodriguez, L., Silva, L.N., and Wingfield, M. J. 2015. Changes in planted forests and future global implications. Forest Ecology and Management 352: 57-67.

Pihlainen, S., Tahvonen, O., and Niinimäki, S. 2014. The economics of timber and bioenergy production and carbon storage in Scots pine stands. Canadian Journal of Forest Research 44(9): 1091-1102.

Pohjola, J., and Valsta, L. 2007. Carbon credits and management of Scots pine and Norway spruce stands in Finland. Forest Policy and Economics 9(7): 789-798.

Pukkala, T., Lähde, E., and Laiho, O. 2009. Growth and yield models for uneven-sized forest stands in Finland. Forest Ecology and Management 258: 207-216.

Pukkala, T., Lähde, E., Laiho, O., Salo, K., and Hotanen, J-P. 2011. A multifunctional comparison of even-aged and uneven-aged forest management in a boreal region. Canadian Journal of Forest Research 41(4): 851-862.

Rämö, J., and Tahvonen, O. 2014. Economics of harvesting uneven-aged forest stands in Fennoscandia. Scandinavian Journal of Forest Research 29(8): 777-792.

Samuelson, P. 1976. Economics of forestry in an evolving society. Economic Inquiry 14(4): 466492. 
Sinha, A., Malo, P., and Deb, K. 2017. A Review on Bilevel Optimization: From Classical to Evolutionary Approaches and Applications. arXiv preprint arXiv:1705.06270.

Solberg, B., and Haight, R.G. 1991. Analysis of optimal economic management regimes for Picea abies stands using a stage-structured optimal-control model. Scandinavian Journal of Forest Research 6: 559-572.

Stainback, G.A., and Alavalapati, J.R.R 2002. Economic analysis of slash pine forest carbon sequestration in the southern U. S. Journal of Forest Economics 8: 105-117.

Surakka, H., and Sirén, M., 2007. Poimintahakkuiden puunkorjuun nykytietämys ja tutkimustarpeet (in Finnish). Metsätieteen aikakauskirja 4/2007: 373-390.

Tahvonen, O., and Rämö, J. 2016. Optimality of continuous cover vs. clearcut regimes in managing forest resources. Canadian Journal of Forest Research 46(7): 891-901.

Thompson, I., Mackey, B., McNulty, S., and Mosseler, A. 2009. Forest Resilience, Biodiversity, and Climate Change. A synthesis of the Biodiversity / Resilience / Stability Relationship in Forest Ecosystems. Technical Series no. 43. Secretariat of the Convention on Biological Diversity, Montreal. $67 \mathrm{p}$.

van Kooten, G., Binkley, C., and Delcourt, G. 1995. Effect of Carbon Taxes and Subsidies on Optimal Forest Rotation Age and Supply of Carbon Services. American Journal of Agricultural Economics 77(2): 365-374.

van Kooten, G.C., Laaksonen-Craig, S., and Wang, Y. 2009. A meta-regression analysis of forest carbon offset costs. Canadian Journal of Forest Research 39(11): 2153-2167.

Wikberg, P-E. 2004. Occurrence, morphology and growth of understory saplings in Swedish forests. Acta Universitatis Agriculturae Suecica. Silvestria 322. 73 p. 
Tables

Table 1. Size class -specific parameter values, per tree.

\begin{tabular}{|c|c|c|c|c|}
\hline Size class & Diameter $(\mathrm{cm})$ & Basal area $\left(\mathrm{m}^{2}\right)$ & $\begin{array}{l}\text { Sawlog volume, } \\
S I=15\left(\mathrm{~m}^{3}\right)\end{array}$ & $\begin{array}{l}\text { Pulpwood volume, } \\
S I=15\left(\mathrm{~m}^{3}\right)\end{array}$ \\
\hline 1 & 7.5 & 0.004 & 0.000 & 0.014 \\
\hline 2 & 12.5 & 0.012 & 0.000 & 0.067 \\
\hline 3 & 17.5 & 0.024 & 0.000 & 0.167 \\
\hline 4 & 22.5 & 0.040 & 0.234 & 0.081 \\
\hline 5 & 27.5 & 0.059 & 0.446 & 0.065 \\
\hline 6 & 32.5 & 0.083 & 0.684 & 0.060 \\
\hline 7 & 37.5 & 0.110 & 0.963 & 0.050 \\
\hline 8 & 42.5 & 0.142 & 1.253 & 0.050 \\
\hline 9 & 47.5 & 0.177 & 1.574 & 0.043 \\
\hline 10 & 52.5 & 0.216 & 1.900 & 0.039 \\
\hline 11 & 57.5 & 0.260 & 2.214 & 0.033 \\
\hline 12 & 62.5 & 0.307 & 2.565 & 0.031 \\
\hline
\end{tabular}

Table 2. Parameter values for the harvesting cost function.

\begin{tabular}{lllllllll}
\hline$i$ & $C_{i 0}$ & $C_{i 1}$ & $C_{i 2}$ & $C_{i 3}$ & $C_{i 4}$ & $C_{i 5}$ & $C_{i 6}$ & $C_{i 7}$ \\
\hline$t h$ & 2.100 & 1.150 & 0.412 & 0.758 & 0.180 & 1.000 & 2.272 & 0.535 \\
$c l$ & 2.100 & 1.000 & 0.397 & 0.758 & 0.180 & 1.000 & 1.376 & 0.393 \\
\hline
\end{tabular}


Table 3. Effect of carbon pricing on optimal stand management, given $€ 1000 \mathrm{ha}^{-1}$ regeneration cost.

\begin{tabular}{|c|c|c|c|c|c|c|}
\hline \multirow[t]{2}{*}{$\begin{array}{l}\text { Interest } \\
\text { rate }\end{array}$} & $\begin{array}{l}\text { Carbon } \\
\text { price }\end{array}$ & $\begin{array}{l}\text { Rotation } \\
\text { age }\end{array}$ & $\begin{array}{l}\text { Timing of first } \\
\text { harvest }\end{array}$ & $\begin{array}{l}\text { Harvest interval } \\
\text { at steady state }\end{array}$ & $\begin{array}{l}\text { Diameters of trees } \\
\text { harvested at } \\
\text { steady state }\end{array}$ & $\begin{array}{l}\text { Mean stand } \\
\text { volume }\end{array}$ \\
\hline & $\left(€ \mathrm{tCO}_{2}^{-1}\right)$ & (years) & $\begin{array}{l}\text { (years from stand } \\
\text { regeneration) }\end{array}$ & (years) & $(\mathrm{cm})$ & $\left(\mathrm{m}^{3} \mathrm{ha}^{-1}\right)$ \\
\hline \multirow[t]{5}{*}{$2 \%$} & 0 & 130 & 45 & - & - & 138 \\
\hline & 10 & 150 & 45 & - & - & 152 \\
\hline & 20 & 170 & 50 & - & - & 174 \\
\hline & 30 & $\infty$ & 50 & 25 & $32.5-52.5$ & 182 \\
\hline & 60 & $\infty$ & 50 & 20 & $37.5-52.5$ & 224 \\
\hline \multirow[t]{5}{*}{$4 \%$} & 0 & $\infty$ & 40 & 20 & $22.5-37.5$ & 68 \\
\hline & 10 & $\infty$ & 45 & 25 & $22.5-42.5$ & 79 \\
\hline & 20 & $\infty$ & 45 & 20 & $27.5-42.5$ & 114 \\
\hline & 30 & $\infty$ & 50 & 20 & $32.5-47.5$ & 169 \\
\hline & 60 & $\infty$ & 55 & 25 & $37.5-57.5$ & 234 \\
\hline
\end{tabular}

Table 4. Effect of carbon pricing on timber production and carbon storage, given $€ 1000$ ha $^{-1}$ regeneration cost.

\begin{tabular}{|c|c|c|c|c|c|c|c|}
\hline $\begin{array}{l}\text { Interest } \\
\text { rate }\end{array}$ & $\begin{array}{l}\text { Carbon } \\
\text { price }\end{array}$ & $\begin{array}{l}\text { Rotation } \\
\text { age }\end{array}$ & $\begin{array}{l}\text { Mean annual } \\
\text { sawlog / total } \\
\text { yield }\end{array}$ & $\begin{array}{l}\text { Mean } \mathrm{CO}_{2} \\
\text { storage in } \\
\text { living trees }\end{array}$ & $\begin{array}{l}\text { Mean } \mathrm{CO}_{2} \\
\text { storage in } \\
\text { dead tree } \\
\text { matter }\end{array}$ & $\begin{array}{l}\text { Mean } \mathrm{CO}_{2} \\
\text { storage in } \\
\text { timber } \\
\text { products }\end{array}$ & $\begin{array}{l}\text { Discounted } \\
\mathrm{CO}_{2} \\
\text { sequestration }\end{array}$ \\
\hline & $\left(€ \mathrm{tCO}_{2}^{-1}\right)$ & & $\left(m^{3} h a^{-1} a^{-1}\right)$ & $\left(\mathrm{tCO}_{2} \mathrm{ha}^{-1}\right)$ & $\left(\mathrm{tCO}_{2} \mathrm{ha}^{-1}\right)$ & $\left(\mathrm{tCO}_{2} \mathrm{ha}^{-1}\right)$ & $\left(\mathrm{tCO}_{2} \mathrm{ha}^{-1}\right)$ \\
\hline \multirow[t]{5}{*}{$2 \%$} & 0 & 130 & $6.3 / 7.6$ & 207 & 53 & 80 & 198 \\
\hline & 10 & 150 & $6.5 / 7.6$ & 227 & 53 & 81 & 213 \\
\hline & 20 & 170 & $6.7 / 7.6$ & 260 & 54 & 83 & 232 \\
\hline & 30 & $\infty$ & $5.7 / 6.0$ & 271 & 43 & 69 & 244 \\
\hline & 60 & $\infty$ & $5.7 / 6.0$ & 335 & 44 & 70 & 269 \\
\hline \multirow[t]{5}{*}{$4 \%$} & 0 & $\infty$ & $3.8 / 4.5$ & 101 & 30 & 48 & 108 \\
\hline & 10 & $\infty$ & $4.0 / 4.7$ & 118 & 32 & 51 & 115 \\
\hline & 20 & $\infty$ & $5.0 / 5.6$ & 170 & 38 & 62 & 123 \\
\hline & 30 & $\infty$ & $5.7 / 6.1$ & 252 & 43 & 70 & 133 \\
\hline & 60 & $\infty$ & $5.6 / 5.8$ & 349 & 43 & 67 & 144 \\
\hline
\end{tabular}


Table 5. Forestry revenues, given $€ 1000 \mathrm{ha}^{-1}$ regeneration cost.

\begin{tabular}{ccccc}
\hline $\begin{array}{c}\text { Interest } \\
\text { rate }\end{array}$ & $\begin{array}{c}\text { Carbon } \\
\text { price }\end{array}$ & $\begin{array}{c}\text { Discounted } \\
\text { timber } \\
\text { income }\end{array}$ & $\begin{array}{c}\text { Discounted } \\
\text { carbon } \\
\text { subsidies } \\
\left(€ \mathrm{tCO}_{2}^{-1}\right)\end{array}$ & $\begin{array}{c}\text { Net present } \\
\text { value }\end{array}$ \\
$\left(€ \mathrm{ha}^{-1}\right)$ & $\left(€ \mathrm{ha}^{-1}\right)$ & $\left(€ \mathrm{ha}^{-1}\right)$ \\
\hline $2 \%$ & 0 & 9863 & 0 & 8780 \\
& 10 & 9791 & 2128 & 10865 \\
& 20 & 9514 & 4648 & 13127 \\
& 30 & 9174 & 7314 & 15488 \\
& 60 & 8000 & 16127 & 23127 \\
\hline $4 \%$ & 0 & 2662 & 0 & 1662 \\
& 10 & 2610 & 1148 & 2758 \\
& 20 & 2483 & 2462 & 3945 \\
& 30 & 2233 & 3992 & 5225 \\
& 60 & 1726 & 8666 & 9392 \\
\hline
\end{tabular}


Figure captions

Figure 1. Stand volume and number of trees, with a $2 \%$ interest rate and carbon prices $€ 0, € 10, € 20$ and $€ 30 \mathrm{tCO}_{2}^{-1}$. Note: $w=€ 1000 \mathrm{ha}^{-1}$.

Figure 2. Stand volume and number of trees, with a $4 \%$ interest rate and carbon prices $€ 0$ and $€ 20$ $\mathrm{tCO}_{2}^{-1}$. Note: $w=€ 1000 \mathrm{ha}^{-1}$.

Figure 3. Optimal steady-state structures expressed as (a) number of trees and (b) commercial volume in each size class, with a $4 \%$ interest rate and carbon prices $€ 0, € 10, € 20$ and $€ 30 \mathrm{tCO}_{2}{ }^{-1}$. Size classes begin from a diameter of $7.5 \mathrm{~cm}$ and increase in 5-cm intervals. Note: $w=€ 1000 \mathrm{ha}^{-1}$.

Figure 4. Total carbon storage, including carbon storage in living trees, dead tree matter and timber products, with a $2 \%$ interest rate and carbon prices $€ 0, € 10, € 20$ and $€ 30 \mathrm{tCO}_{2}{ }^{-1}$. Note: $w=€ 1000 \mathrm{ha}^{-1}$.

Figure 5. Marginal abatement costs. Note: $w=€ 1000 \mathrm{ha}^{-1}$. 
(a) $p_{c}=€ 0 \mathrm{tCO}_{2}^{-1}$

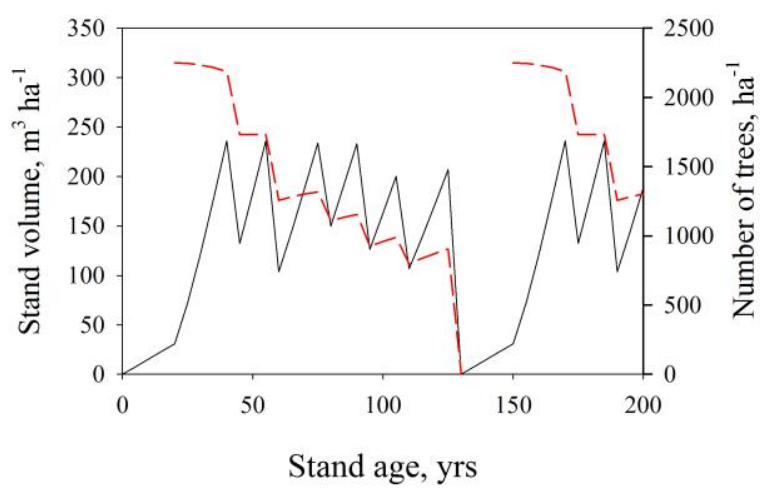

(c) $p_{c}=€ 20 \mathrm{tCO}_{2}^{-1}$

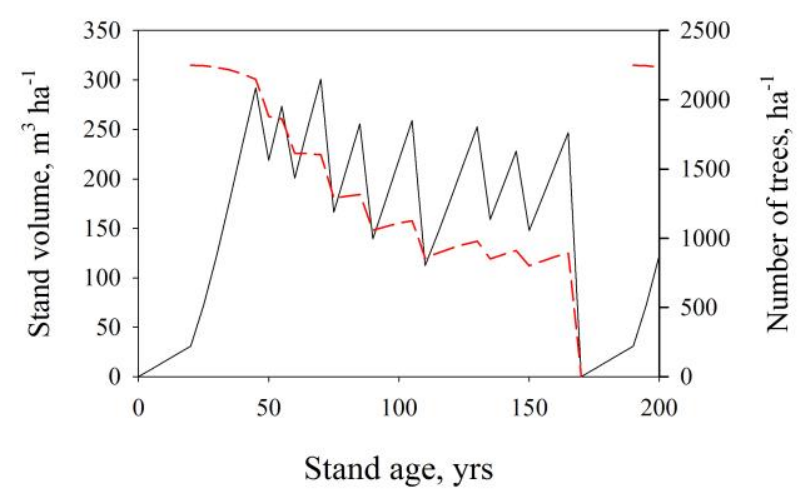

(b) $p_{c}=€ 10 \mathrm{tCO}_{2}^{-1}$

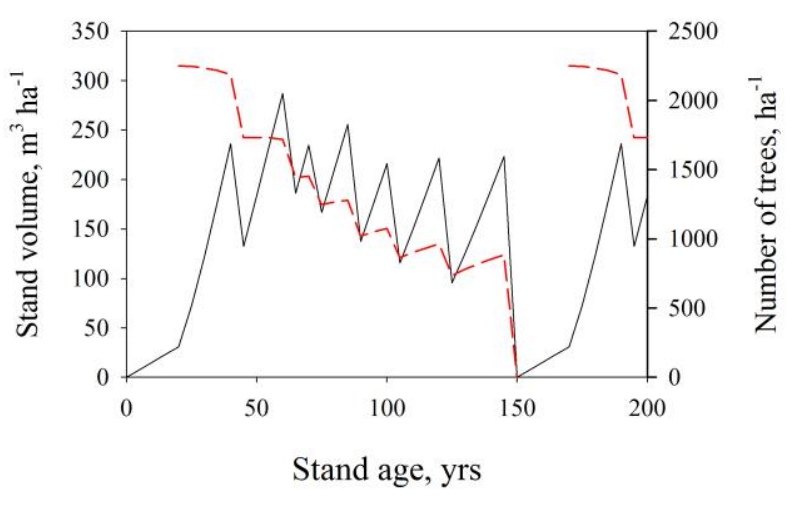

(d) $p_{c}=€ 30 \mathrm{tCO}_{2}^{-1}$

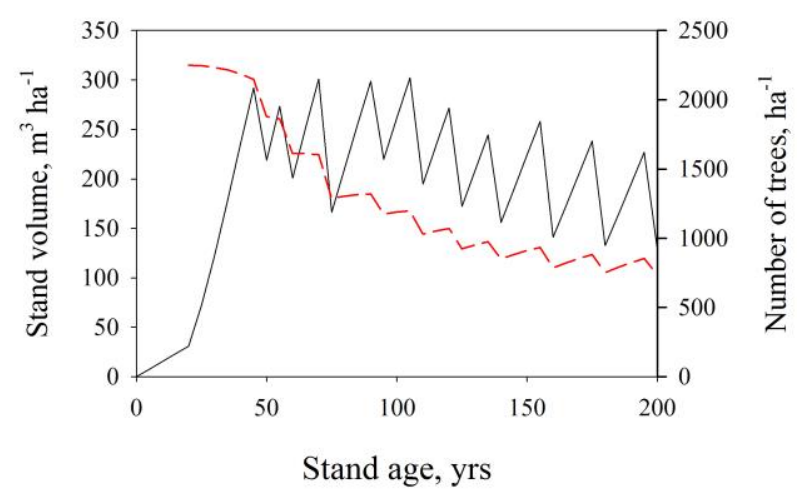

Number of trees, $\mathrm{ha}^{-1}$ (a) $p_{c}=€ 0 \mathrm{tCO}_{2}^{-1}$

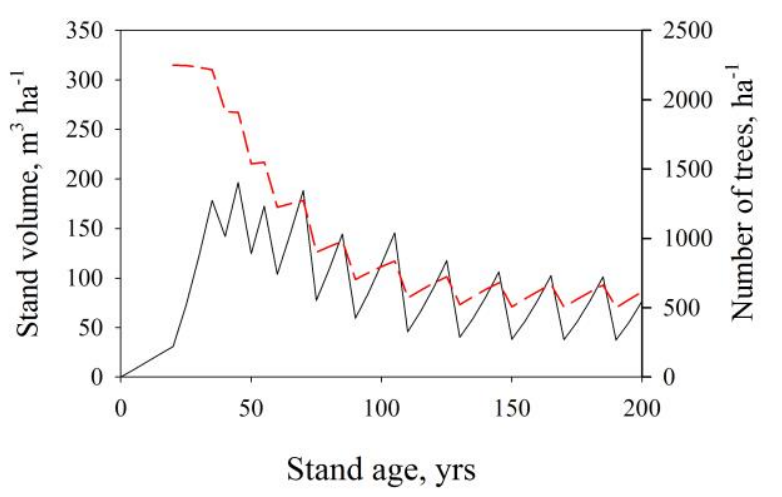

(b) $p_{c}=€ 20 \mathrm{tCO}_{2}^{-1}$

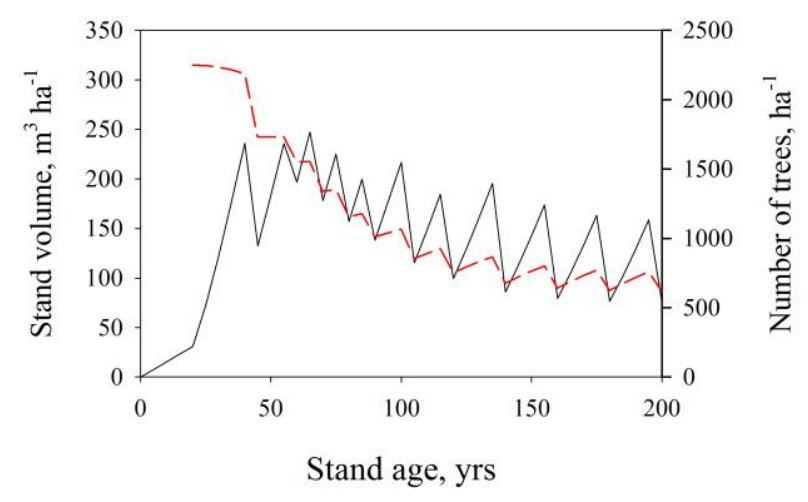

Stand volume, $\mathrm{m}^{3} \mathrm{ha}^{-1}$

--- Number of trees, $\mathrm{ha}^{-1}$ 
(a)

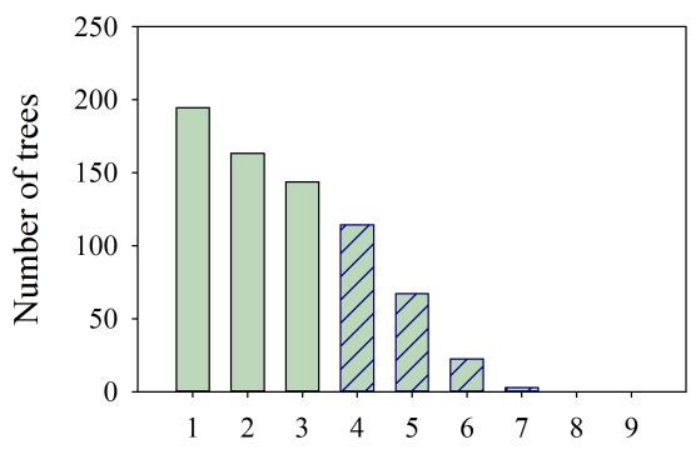

Size class

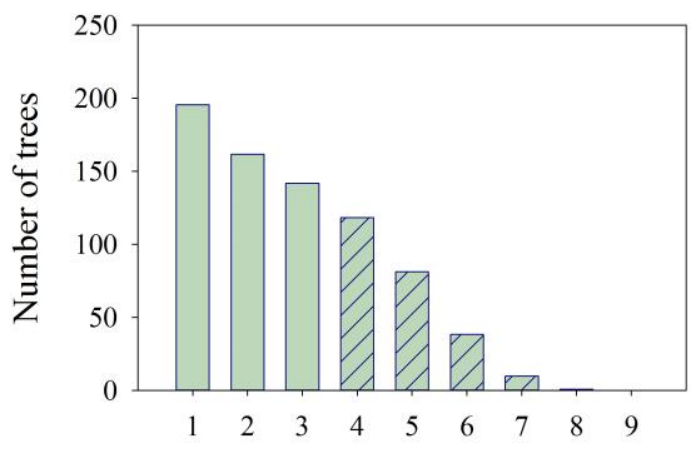

Size class

$$
p_{c}=€ 20 \mathrm{tCO}_{2}^{-1}
$$

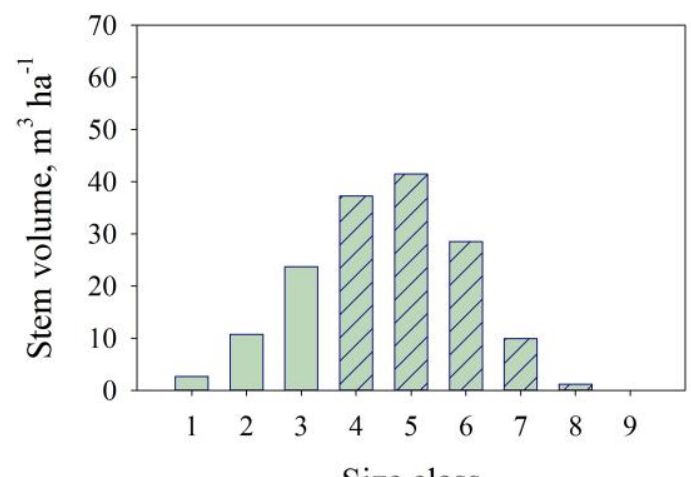

Size class

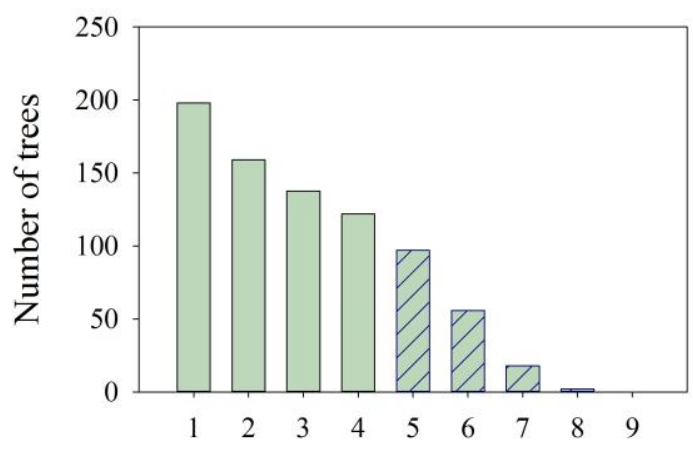

Size class

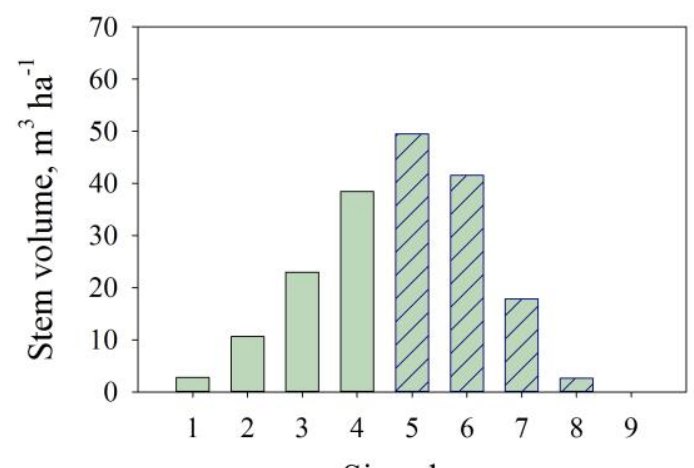

Size class

$p_{c}=€ 30 \mathrm{tCO}_{2}^{-1}$
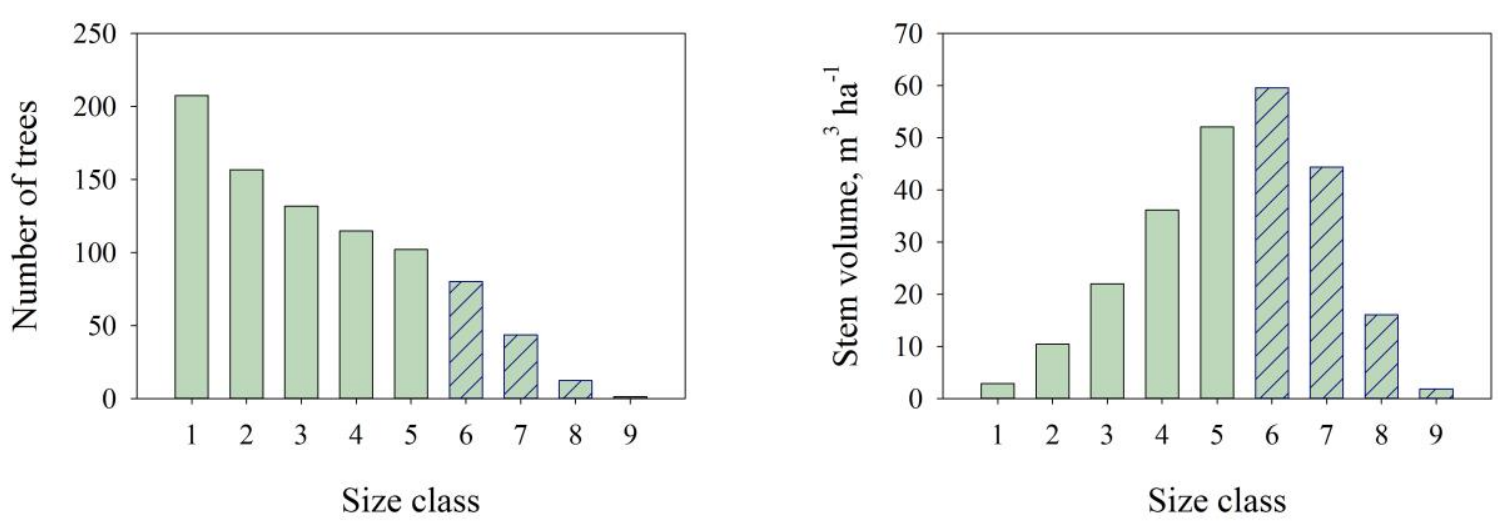

Standing trees after harvest

VI/ Harvested trees 
(a) $p_{c}=€ 0 \mathrm{tCO}_{2}^{-1}$

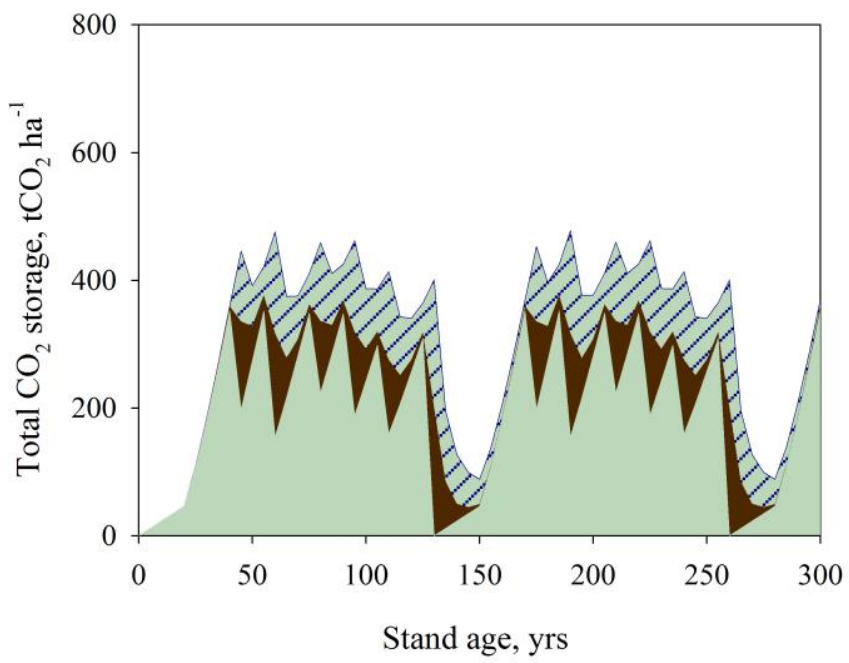

(c) $p_{c}=€ 20 \mathrm{tCO}_{2}^{-1}$

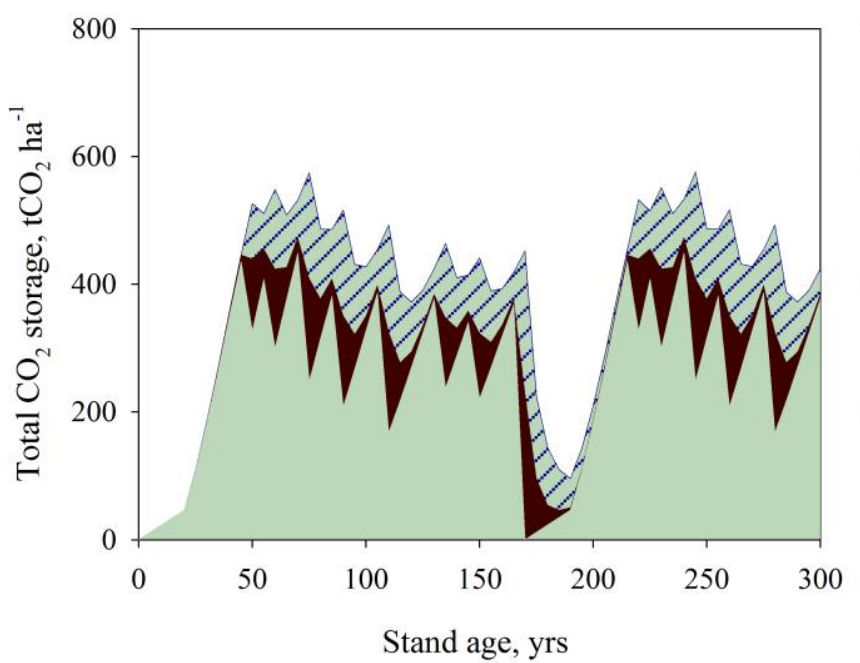

(b) $p_{c}=€ 10 \mathrm{tCO}_{2}^{-1}$

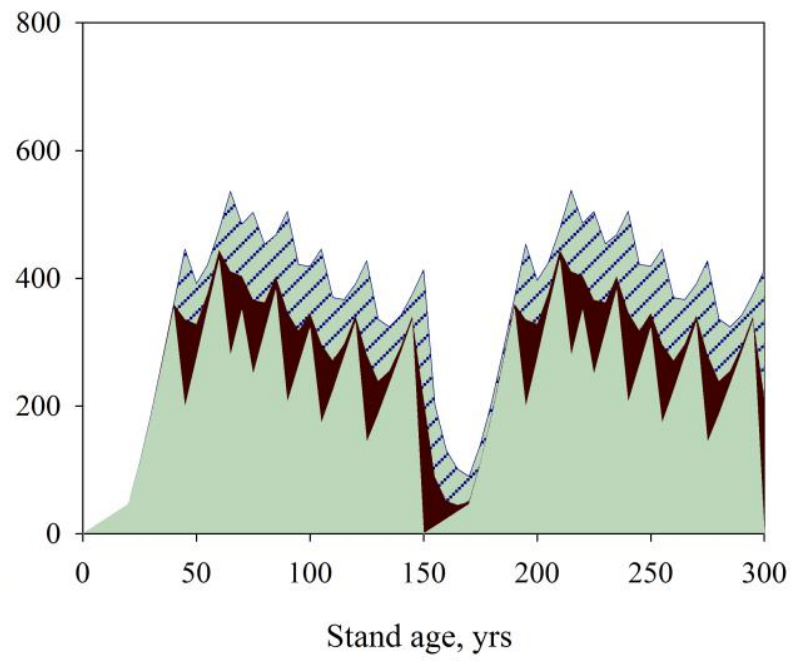

(d) $p_{c}=€ 30 \mathrm{tCO}_{2}^{-1}$

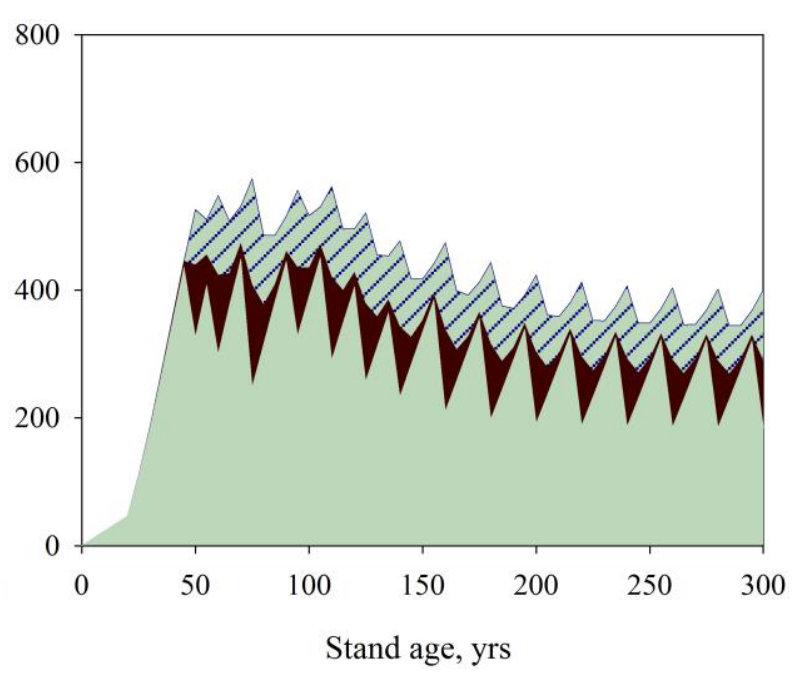

In living trees

In dead tree matter

$\measuredangle \measuredangle \triangle$ In timber products 


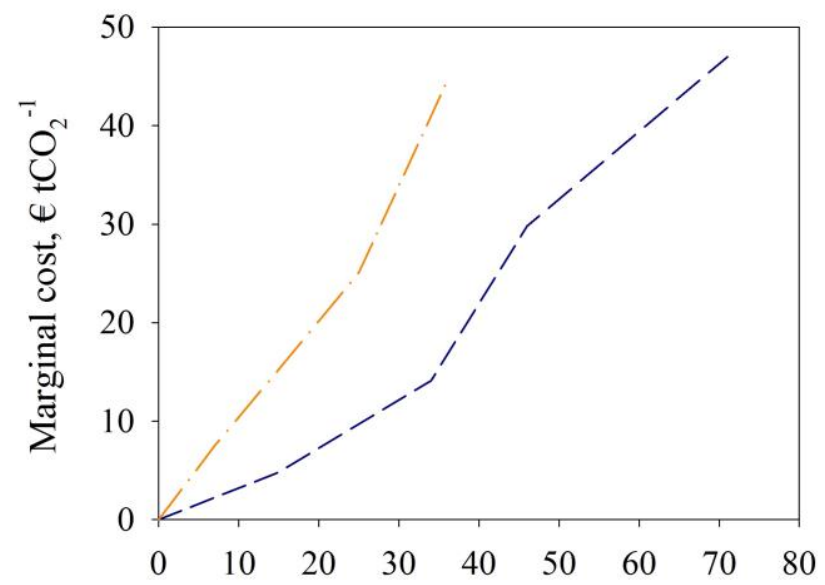

Carbon abatement, $\mathrm{tCO}_{2} \mathrm{ha}^{-1}$

- - - $-2 \%$ interest rate

- _. $4 \%$ interest rate 